\title{
Smoke trails of a dying gut: portal and mesenteric vein gas
}

\author{
Sainath Gaddam, ${ }^{1}$ Ashish Koirala, ${ }^{1}$ Krishna C Nimmagadda, ${ }^{2}$ Pavneet S Kohli, ${ }^{1}$ Robert V Wetz, \\ Theodore Maniatis ${ }^{3}$
}

${ }^{1}$ Department of Internal Medicine, Staten Island University Hospital, Staten Island, New York, USA
${ }^{2}$ Massachusetts General Hospital, Boston, Massachusetts, USA

${ }^{3}$ Division of Critical Care Medicine, Staten Island University Hospital, Staten Island, New York, USA

Correspondence to Sainath Gaddam, gaddamsainath@gmail.com

\section{DESCRIPTION}

A 49-year-old male, status postresection of melanoma 2 years ago, presented with constipation, abdominal pain and abdominal distension for the last 1 week. CT abdomen with contrast showed small bowel obstruction and a transition point was identified in the central abdomen (figure 1). Also noted were innumerable hepatic and splenic metastases (figure 2), and innumerable abdominal lymph nodes, largest one measuring $6.9 \mathrm{~cm}$. After $3 \mathrm{~h}$, a repeat CT abdomen was performed to look for delayed passage of contrast beyond the transition point. In this interim, the patient developed small bowel pneumatosis, with new mesenteric and portal venous gas (figures 3 and 4). An emergency laparotomy was performed. The entire mid small bowel was covered with fibrinous exudate with evidence of ischaemia and perforation. Ischaemia and obstruction was from strangulation of the small bowel due to lymph node adhesions and external compression by massively enlarged lymph

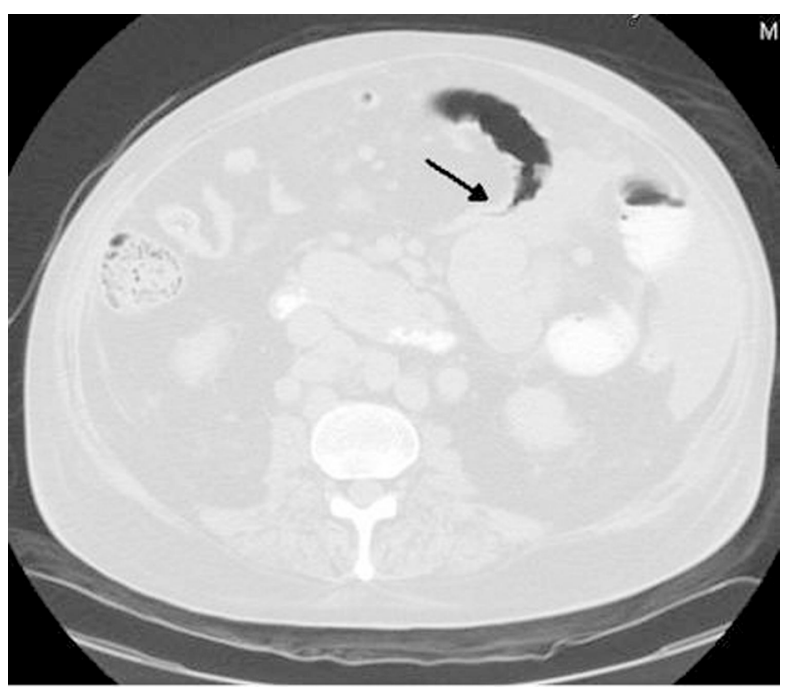

Figure 1 Point of transition, with proximal dilatation and distal collapse of small bowel. nodes. A wide mesenteric resection was carried out incorporating all the large lymph nodes in the area of perforation. A primary anastomosis was performed between the ileum and the mid jejunum. Postsurgery, the patient remained mechanically ventilated with pressure support, but the family decided to withdraw all the supportive measures and the patient expired in 2 days.

This rare radiological sign was first described by Wolfe and Evans ${ }^{1}$ in neonates secondary to necrotising enterocolitis. It is believed that air leaks through the obstructed gut into capillary veins due to perforation of ischaemic intestinal wall. The treatment and prognosis of portal venous gas depends on the underlying cause. ${ }^{2}$ In adults, it is mostly seen secondary to bowel ischaemia, hence requires emergency laparotomy and carries a high mortality. ${ }^{3}$ This sign is also reported in some benign conditions requiring only conservative management. ${ }^{4}$

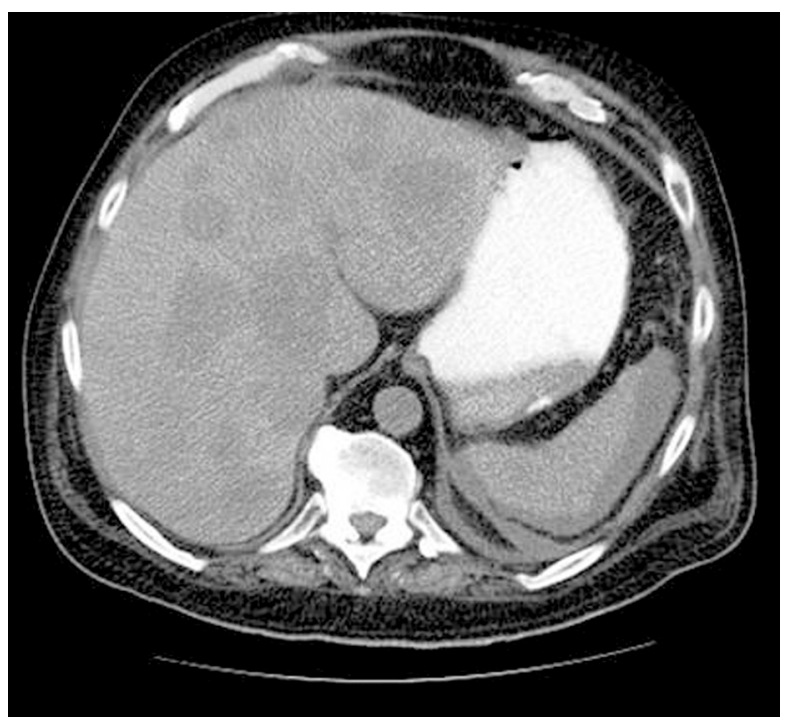

Figure 2 Multiple hepatic metastases and no hepatic portal venous gas is seen at presentation. 


\section{BMJ Case Reports}

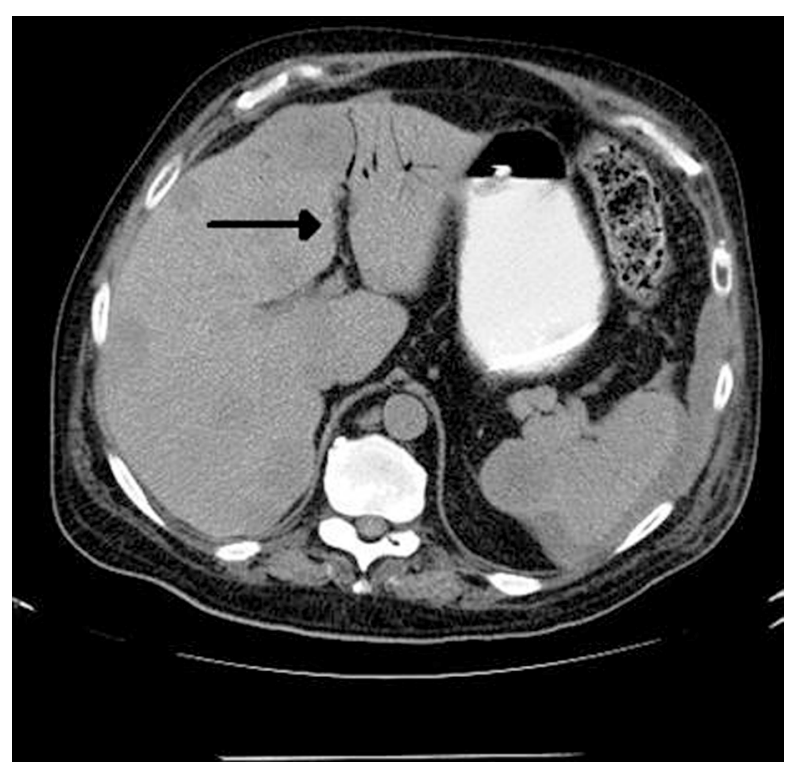

Figure 3 Repeat CT, done $3 \mathrm{~h}$ later, showing hepatic portal venous gas.

Competing interests None

Patient consent Obtained.

\section{REFERENCES}

1. Wolfe JN, Evans WA. Gas in the portal veins of the liver in infants; a roentgenographic demonstration with postmortem anatomical correlation. Am J Roentgenol Radium Ther Nucl Med 1955:74:486-8.

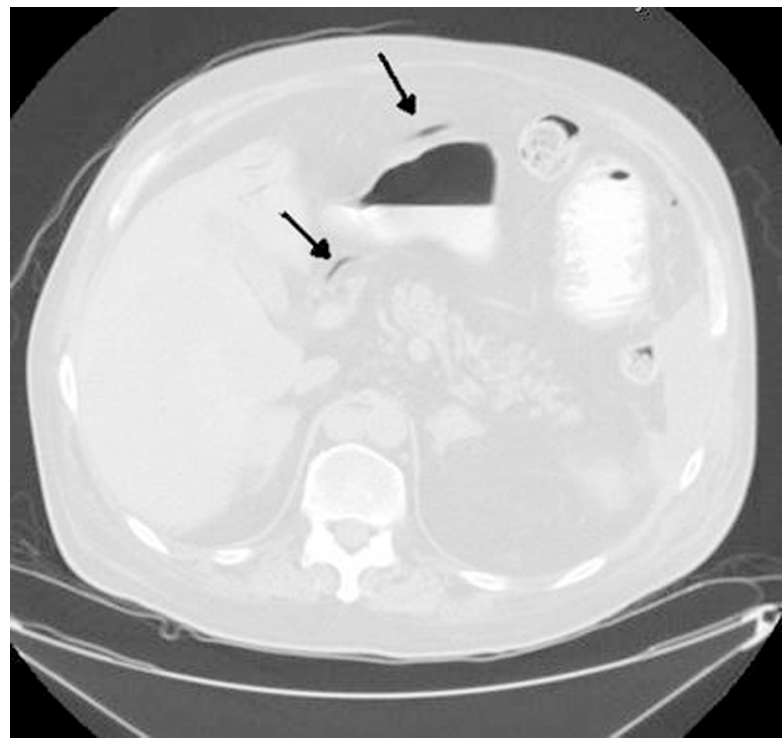

Figure 4 Mesenteric vein gas can be noticed, like smoke trails of a dying tissue.

2. Nelson AL, Millington TM, Sahani D, et al. Hepatic portal venous gas: the ABCs of management. Arch Surg 2009;144:575-81; discussion 581.

3. Liebman PR, Patten MT, Manny J, et al. Hepatic-portal venous gas in adults: etiology, pathophysiology and clinical significance. Ann Surg 1978;187:281-7.

4. Nobili C, Uggeri F, Romano F, et al. Pylephlebitis and mesenteric thrombophlebitis in sigmoid diverticulitis: medical approach, delayed surgery Dig Liver Dis 2007;39:1088-90.

This pdf has been created automatically from the final edited text and images.

Copyright 2010 BMJ Publishing Group. All rights reserved. For permission to reuse any of this content visit http://group.bmj.com/group/rights-licensing/permissions.

BMJ Case Report Fellows may re-use this article for personal use and teaching without any further permission.

Please cite this article as follows (you will need to access the article online to obtain the date of publication)

Gaddam S, Koirala A, Nimmagadda KC, Kohli PS, Wetz RV, Maniatis T. Smoke trails of a dying gut: portal and mesenteric vein gas. BMJ Case Reports 2010; 10.1136/bcr.01.2010.2660, date of publication

Become a Fellow of BMJ Case Reports today and you can:

Submit as many cases as you like

- Enjoy fast sympathetic peer review and rapid publication of accepted articles

- Access all the published articles

- Re-use any of the published material for personal use and teaching without further permission

For information on Institutional Fellowships contact consortiasales@bmjgroup.com

Visit casereports.bmj.com for more articles like this and to become a Fellow 